TEME, г. XLIV, бр. 2, април - јун 2020, стр. 339-354

Прегледни рад $\quad$ https://doi.org/10.22190/TEME180703030R

Примљено: 3. 7. 2018.

UDK $371.3:: 811.133 .1$

Ревидирана верзија: 28. 4. 2019.

Одобрено за штампу: 15. 4. 2020.

\title{
ЈЕЗИЧКА НОРМА И ОДНОС ПРЕМА ЈЕЗИЧКОЈ \\ ВАРИЈАЦИЈИ У НАСТАВИ ФРАНЦУСКОГ КАО \\ СТРАНОГ ЈЕЗИКА: ПРИМЕР УПОТРЕБЕ ДИРЕКТНОГ ПАРЦИЈАЛНОГ ПИТАЊА СА УПИТНИМ ПРИЛОЗИМА ${ }^{a}$
}

\author{
Наташа Радусин-Бардић
}

Универзитет у Новом Саду, Филозофски факултет, Нови Сад, Србија radusin.bardic@gmail.com

\begin{abstract}
Апстракт
У савременој настави француског као страног језика приметни су различити ставови у погледу дефинисања језичке варијације, у зависности од тога да ли се посматра из угла традиционално схваћеног узорног језичког нивоа le bon usage, са становишта пропозиција „основног француског језика”, на којима се темељи АВГС методологија, или са појавом комуникативног приступа у настави страних језика, из перспективе умерено конзервативног и флексибилног односа према конзервативној језичкој норми. Како бисмо на конкретном примеру проучили како се језичка варијација третира у настави француског као страног језика, наше истраживање засновали смо на анализи употребе различитих облика за исказивање директног парцијалног питања уз упитне прилоге où, quand, comment и pourquoi у седам одабраних метода које су објављене од средине прошлог века до данас. Резултати квалитативне и квантитативне анализе наведених упитних облика у одабраним методама показују значајне осцилације у погледу заступљености упитних облика изведених помоћу инверзије и оних у којима је, противно конзервативној језичкој норми, а у складу са општим тенденцијама у француском говорном језику, задржан ред речи својствен изјавној реченици. Добијени резултати указују на изражену потребу за конзистентнијим прагматичким дефинисањем језичке варијације у савременој настави француског као страног језика.
\end{abstract}

Кључне речи: француски као страни језик, језичка норма, језичка варијација, парцијално питање, упитни прилози.

\footnotetext{
${ }^{a}$ Овај чланак представља резултат рада на пројекту Језици и културе у времену $и$ nростору (број 178002), који финансира Министарство просвете, науке и технолошког развоја Републике Србије.
} 


\title{
LINGUISTIC NORMS AND THE RELATIONSHIP TOWARDS LINGUISTIC VARIATION IN TEACHING FRENCH AS A FOREIGN LANGUAGE: EXAMPLES OF THE USE OF DIRECT PARTIAL QUESTIONS WITH INTERROGATIVE ADVERBS
}

\begin{abstract}
Different attitudes towards the definition of linguistic variations are noticeable in contemporary teaching of French as a foreign language. The difference depends on whether it is viewed from the perspective of traditionally understood exemplary linguistic levels le bon usage, from the standpoint of propositions - the "basic French language" the SGAV methodology is based on; or with the emergence of a communicative approach in foreign language teaching from the perspective of a moderately conservative and flexible attitude towards conservative linguistic norms. In order to study how linguistic variations in the teaching of French as a foreign language are treated, our research was based on an analysis of the use of different forms for expressing a direct partial question with interrogative adverbs où, quand, comment and pourquoi in seven selected methods published from the middle of the last century until the present day. The results of the qualitative and quantitative analyses of the abovementioned interrogative forms in the selected methods, illustrate significant oscillations in terms of the representation of interrogative forms derived from inversion and those which, contrary to the conservative linguistic norm and in accordance with the general tendencies in the French spoken language, preserve the word order characteristic of a statement. The obtained results indicate an expressed need for a more consistent pragmatic definition of linguistic variation in the contemporary teaching of French as a foreign language.
\end{abstract}

Key words: French as a foreign language, linguistic norm, linguistic variation, partial question, interrogative adverbs.

\section{УВОД}

У методици наставе француског као страног језика једно од најчешће постављаних питања гласи: Quel français enseigner? („Који француски језик треба да буде заступљен у настави?”) (Bibeau \& Germain, 1983; Boyer \& Rivera, 1979; Boyer, Butzbach-Rivera \& Pendanx, 1990; Coste, 1969). Одговор на ово питање предмет је вечито актуелне полемике свих учесника у организацији наставе француског као страног језика, а зависи од усвојеног односа према језичкој норми и језичкој варијацији у складу са примењеним педагошко-дидактичким начелима.

Предмет нашег рада јесте анализа језичке варијације на примеру употребе различитих облика за исказивање директног парцијалног питања уз упитне прилоге où, quand, comment и pourquoi у методама за учење француског као страног језика објављеним од средине прошлог века до данас. Наиме, управо синтаксичке структуре за исказивање интерогативног модалитета у француском језику, а посебно за исказивање парцијалног питања уз упитне прилоге ой, 
quand, comment и pourquoi - показују висок степен варијације будући да изворни говорници паралелно користе више облика различитих стилских вредности за исказивање истог упитног значења. Тако, на пример, питање: „Како се зовеш?” може бити постављено на француском језику на најмање четири начина:

a) Помоћу просте инверзије иза упитног прилога у иницијалној позицији (Comment t'appelles-tu?);

б) Уз очуван канонски ред речи (субјекат + предикат + објекат) посредством упитног израза est-ce que иза упитног прилога у иницијалној позицији (Comment est-ce que tu t'appelles?);

в) Уз очуван канонски ред речи, коме следи упитни прилог у финалној позицији (Tu t'appelles comment?);

г) Уз непосредно очуван канонски ред речи иза упитног прилога у иницијалној позицији (Comment tu t'appelles?).

Напоменимо и то да, када би у функцији субјекта била именица или именска група (нпр. „Како се зове твој брат?”), језичка норма захтевала би употребу просте инверзије где именица или цела именска група стоји иза глагола (Comment s'appelle ton frère?) или сложене инверзије где се субјекат употребљен после упитног прилога понавља, иза глагола у личном глаголском облику, у одговарајућем облику личне ненаглашене заменице 3. лица једнине или множине: Comment ton frère s'appelle-t-il?.

Изостављањем инверзије и успостављањем канонског реда речи у формулацији упитних исказа долази до удаљавања од конзервативне језичке норме, које је нарочито очигледно у формулисању упитног облика под г), које је директно супротстављено стандарднојезичком упитном облику под а). Међутим, као што су то показале бројне анализе корпуса француског разговорног језика, управо су упитни облици под в) и г) и, у мањој мери, под б) најзаступљенији у свакодневном, односно неформалном, говору упркос томе што мање или више одступају од традиционално схваћеног узорног језичког нивоа le bon usage (Coveney, 2002, стр. 111; Valdman, 1982, стр. 225).

Пре него што прикажемо методологију и резултате нашег истраживања, као и његове могуће педагошке импликације, желели бисмо укратко да представимо како се проблематика дефинисања језичке норме и односа према језичкој варијацији третира у доминантним методолошким правцима који су обележили савремену наставу француског језика.

ЈЕЗИЧКА НОРМА И ОДНОС ПРЕМА ЈЕЗИЧКОЈ ВАРИЈАЦИЈИ У САВРЕМЕНОЈ НАСТАВИ ФРАНЦУСКОГ КАО СТРАНОГ ЈЕЗИКА

Чувени методичари наставе француског као страног језика Анри Боаје (Henri Boyer) и Мишел Ривера (Michèle Rivera), увиђају- 
ћи значај језичке варијације, залагали су се за уважавање језичке хетерегености и износили су став према којем је немогуће слепо се потчињавати само једној норми писаног или чак говорног француског језика, па макар она и носила назив le «bon» usage (,,правилна" употреба) (Boyer et al., 1979, стр. 30). Међутим, када је реч о настави француског као страног језика, нарочито на почетном нивоу, неопходно је говорити о селекцији, приоритетима и фазама учења. Према њиховом схватању, у раној етапи учења не треба подстицати учење паралелних језичких облика који преносе исто референтно значење, него треба тежити ка овладавању основама француског језика које омогућавају несметану комуникацију. Овакав став износио је и Данијел Кост (Daniel Coste) истичући нужност увођења ригорозне квалитативне селекције, која мора бити хомогена, нарочито на почетку учења (Coste, 1969, стр. 16). Учење треба да буде засновано на неутралном говорном и писаном језику који не одликује ни претерана фамилијарност, ни скученост уштогљеног језика, већ то треба да буде „уобичајени језик” који изворни говорници свакодневно употребљавају (фр. la langue usuelle) (Ibid.).

$\mathrm{У}$ наведеним ставовима видимо утицај принципа које су истицали аутори „основног француског језика” (фр. le français fondamental) крајем педесетих и почетком шездесетих година прошлог века: Како би се осигурало ефикасно усвајање неког језика, неопходно је издвојити основне елементе који ће сачињавати темељ сваке касније етапе учења (Gougenheim, Michéa, Rivenc \& Sauvageot, 1964, стр. 11). Израда речника и граматике „основног француског језика”, који чине окосницу АВГС (аудио-визуелне глобално-структуралне) методологије, представља значајну прекретницу у настави француског као страног језика, која је пре тога била исувише дуго заснована на „педагошком емпиризму и потчињавању писаном, најчешће књижевном, језику" (Boyer et al., 1979, стр. 35). Међутим, иако је значај овог пројекта несумњив, он није испунио сва очекивања, о чему сведоче бројне дидактичке полемике по питању норме и варијације у настави француског као страног језика, које су остале актуелне и до дана данашњег. Према речима А. Боајеа и М. Ривере, аутори наведеног пројекта желели су да издвоје немаркирану језичку грађу у погледу друштвено-културне варијације како би она послужила за израду уџбеничког материјала, али приликом њене строге педагошке примене, подређене прогресији, апстрахована језичка грађа уткана је у стерилне дијалоге који су изгубили свежину живе речи, те се отуда јавља све већа тежња ка аутентичним изворима или макар онима у којима би успешнија адаптација верније дочаравала разноврсност говорних ситуација (Ibid., стр. 39). Ако на почетку не треба обесхрабрити учење исувише наглим излагањем аутентичној језичкој варијацији, није пожељна ни сувише дуга употреба вештачких дијалога скованих по 
узору на „основни француски језик” (Ibid., стр. 50-51), који не пружају довољан увид у реалне облике комуникације са којима ће се ђаци врло вероватно суочити по изласку из учионице, у вербалној интеракцији са изворним говорницима. Наиме, иако се сви у великој мери служе „основним француским језиком”, нико не говори на „основном француском језику” (Galisson, 1980, стр. 24).

Шездесетих и седамдесетих година прошлог века јављају се захтеви за осавремењивањем и проширењем лексичког фонда „основног француског језика”, али и за организовањем наставе француског као страног језика у зависности од реалних потреба и циљева учења који нису једнаки за све. Комуникативни приступ у учењу страних језика развија се из тежње да се задовољи све израженији захтев савременог друштва за што бржим постизањем функционалне комуникативне компетенције на страном језику. За разлику од структуралистичког приступа, који је тежио ка усвајању општеприменљивих, стилски немаркираних модела реченица, са продором теорије говорних чинова и комуникативног приступа у учењу страних језика, у први план долази језичка варијација где „иста илокуциона вредност поприма различита обличја у зависности од конкретних услова реализације говорног чина" (Boyer et al., 1990, стр. 46).

Општи циљ учења страних језика према АВГС методологији и комуникативном приступу исти је утолико што се у оба случаја тежи ка успостављању комуникације, али се пут до остваривања тог циља на различите начине поставља: микролингвистички у АВГС методологији и макролингвистички у комуникативном приступу (Galisson, 1980, стр. 37). Наиме, док се у АВГС методологији инсистира, пре свега, на усвајању лингвистичке компетенције циљног језика, у комуникативном приступу тежи се ка стицању шире схваћене комуникативне компетенције, у оквиру које лингвистичка компетенција чини само једну компоненту, а она је употпуњена бројним другим, не мање важним, ванјезичким елементима, релевантним за успостављање успешне комуникације на циљном језику (социолингвистички, психолошки, прагматички, културолошки и други елементи) (Ibid., стр. 13-14).

У комуникативном приступу је ученик (фр. apprenant) у средишту наставног процеса, уважавају се разлике у индивидуалној мотивацији и потреби за учењем страних језика. У зависности од циља учења страног језика, организује се наставна грађа, чија селекција није формалног, него функционалног типа. Према томе, за разлику од АВГС методологије, у којој је селекција наставне грађе била једнака за све, унапред омеђена лексичким репертоаром и граматичким пропозицијама „основног француског језика”, у комуникативном приступу отвара се пут ка језичкој варијацији, која добија значајну улогу у стицању комуникативне компетенције. 
У последње непуне две деценије, методику наставе француског као страног језика одликује, у великој мери, примена препорука из „Заједничког европског референтног оквира за језике: учење, настава, оцењивање” (ЗЕРОЈ), који је заснован на принципу „акционе педагогије” (фр. pédagogie actionnelle) или „педагогије задатка” (фр. pédagogie par la tâche). Како би се испунио одређени циљ и извршио „задатак” (фр. tâche) у датом контексту, друштвени актери стратешки бирају и служе се различитим компетенцијама којима располажу. Међу њима, они употребљавају „компетенцију вербалне комуникације" (фр. compétence à communiquer langagièrement), која ce caстоји из три компоненте: лингвистичке, социолингвистичке и прагматичке (CECR, 2000, стр. 15). Стављање у исту раван „лингвистичке” са „социолингвистичком” и „прагматичком” компонентом указује, између осталог, и на значајно место које се даје језичкој варијацији у ЗЕРОЈ-у. Истиче се да је одавно познато да језик варира у зависности од контекста, те да, у том смислу, ,језик није неутрално изражајно средство мисли као што то може бити, на пример, математика" (Ibid., стр. 41). Наиме, „потреба и жеља за комуникацијом настају из одређене ситуације, те форма, као и садржај комуникације, одговарају тој ситуацији" (Ibid.).

Према ЗЕРОЈ-у, у почетним фазама учења (A1, А2, Б1), примереним се сматра „неутрални” језички регистар јер ће се „вероватно на том регистру изворни говорници обраћати странцима и непознатима, а то је и регистар који они очекују од њих" (Ibid., стр. 94). Наиме, упознавање са формалнијим и неформалнијим видовима изражавања стиче се с временом, нарочито кроз фазу рецепције. Такође се напомиње да је потребно опрезно се служити формалнијим и неформалнијим регистрима јер њихова недолична употреба може изазвати неспоразуме или чак подсмех. Тек од нивоа Б2, „социолингвистичка корекција" (фр. correction sociolinguistique) омогућава изражавање „у формалном или неформалном регистру у зависности од ситуације и особа које су укључене у комуникацију", као и одржавање комуникације са изворним говорницима на тај начин да они не прилагођавају свој начин изражавања странцима, већ да задржавају исти облик обраћања својствен вербалној интеракцији међу изворним говорницима (Ibid., стр. 95).

\section{МЕТОДОЛОГИЈА ИСТРАЖИВАЬА}

За потребе нашег истраживања језичке варијације на примеру употребе различитих облика за исказивање директног парцијалног питања уз упитне прилоге où, quand, comment и pourquoi, одабрали смо седам почетничких метода за учење француског као страног језика, које су настале под утицајем доминантних методолошких праваца у настави страних језика од средине прошлог века до данас: 
1) Традиционална граматичка метода заснована на језичкој норми le bon usage: Cours de langue et de civilisation françaises: à l'usage des étrangers, I ( $I^{e r}$ et $2^{e}$ degrés) (Mauger, Lamaison \& Hameau, 1953) - ова метода својевремено популарно је звана Le Mauger Bleu по главном аутору и боји корица уџбеника, те ћемо тај назив и ми користити у наставку рада.

2) Аудио-визуелне методе које одражавају норму „основног француског језика":

а) АВГС метода: Франиуски: аудио-визуелна метода. Курс франиуског језика (Gauvenet, Guberina, Neveu, Rivenc \& Vettier, 1971);

б) Метода која комбинује принципе аудио-оралне и АВГС методологије: Le Français et la vie, 1 (Mauger Bruézière, Mercier \& Geffroy, 1971).

3) Методе у којима је заступљен комуникативан приступ учењу француског као страног језика и, у новије време, утицај акционе педагогије, у којима се однос према језичкој норми и језичкој варијацији може дефинисати двојако:

a) Језичка норма је умерено конзервативна и језичка варијација је у мањој мери присутна: Le nouveau sans frontières, 1 (Dominique, Girardet, Verdelhan \& Verdelhan, 1988) и Écho, Al (Girardet, Pécheur \& Gibbe, 2008);

б) Језичка норма је флексибилна и језичка варијација је у већој мери присутна: Teтpo, 1 (Bérard, Canier \& Lavenne, 1996) и Escales, 1 (Blanc, Cartier \& Lederlin, 2002).

Док су у прве две скупине уврштене оне методе код којих је однос према језичкој норми и језичкој варијацији унапред задат (заснован на прескриптивном језичком нивоу le bon usage или на пропозицијама „основног француског језика”), у трећој скупини обједињене су оне методе код којих долази до мањег или већег удаљавања од традиционално схваћеног узорног језичког нивоа.

\section{РЕЗУЛТАТИ ИСТРАЖИВАЬА}

У свим наведеним методама анализирано је укупно 621 директно парцијално питање уз упитне прилоге où, quand, comment и pourquoi (у обзир су узети само упитни облици употребљени уз глагол у личном глаголском облику). У наставку нашег рада, за сваку методу укратко ћемо представити како њени аутори дефинишу принципе на којима је заснована и евентуално одређују однос према језичкој норми и језичкој варијацији, након чега ћемо изнети квалитативне и квантитативне податке о анализираним упитним облицима. 
Традиционална граматичка метода: „le bon usage”

Метода Le Mauger Bleu (Mauger et al., 1953) била је веома заступљена у настави француског као страног језика током педесетих и почетком шездесетих година прошлог века. Ова метода је „традиционална граматичка" због тога што је њен садржај организован тако да следи прогресију граматичких целина из традиционалних граматика француског језика намењених изворним говорницима. Када је реч о томе на „којем француском језику” је метода заснована, у предговору Марка Бланпена (Marc Blancpain), генералног секретара Француске алијансе, јасно се истиче да није у питању „осредњи француски језик”, односно „поједностављени”, „осиромашени језик”, него је представљен француски језик који пружа приступ ,једној од најбогатијих цивилизација на свету”, омогућава, пре свега, „богаћење и неговање духа изучавањем знаменитих књижевних дела" (Mauger et al., 1953, стр. VI). Према томе, будући да је заснована на књижевном језику, не чуди нас то да се у овој методи анализирана директна парцијална питања исказују искључиво у инверзији, док остали упитни облици уопште нису заступљени. Од укупно 102 анализирана питања, забележена су 93 питања (91\%) у простој инверзији (нпр. Où entre-t-il?, Quand se lève-t-il?, Comment fait-il sa toilette?, Pourquoi a-t-il écrit?) и 9 питања (9\%) у сложеној инверзији (нпр. Où M. Vincent sera-t-il correspondant de son journal?, Quand les Vincent auront-ils leurs passeports?, Comment la lettre partira-t-elle?, Pourquoi Hélène est-elle triste?).

\section{Аудио-визуелне методе: норма „основног франиуског језика”}

У складу са принципима АВГС методологије, у предговору методе Франиуски: аудио-визуелна метода. Курс франиуског језика (Gauvenet et al., 1971) инсистира се на језику као вербалном изразу стварности и на његовој неодвојивости од ситуације, која се дочарава посредством комплементарних аудио-визуелних средстава. Језички механизми, изложени у конкретним ситуацијама, представљени су у светлу функционалне граматике. Инсистира се на приоритету говорног над писаним видом испољавања језика. Одабир језичке грађе заступљене у настави врши се на основу формалних и функционалних вредности, те се прави поређење са типкама на тастатури писаће машине, на којој „има типки којима се стално служимо и чији прилаз треба бити лаган и брз, док друге којима се мање служимо могу бити удаљеније од прстију” (Ibid.). У наведеној методи забележена су укупно 34 анализирана директна парцијална питања и сви упитни облици изведени су помоћу просте инверзије (нпр. Où allezvous?, D'où venez-vous?, Quand viens-tu me voir?, Pourquoi allez-vous à la gare?). Међутим, треба напоменути да се упитни прилози често 
употребљавају и самостално, нарочито pourquoi, те се тако ипак избегава честа употреба инверзије (нпр. Vous vous levez très tôt. Pourquoi? - Parce que je travaille à 8 heures.).

Помоћу аудио-визуелне методе Le Français et la vie, 1 (Mauger et al., 1971) настоји се пренети „користан и леп језик”, који ни у ком случају неће бити „сажет или осиромашен”, него „правилан и узоран", чије ће усвајање тећи у складу са одређеном прогресијом (Ibid., стр. IV). На основу анализе упитних облика, може се извести закључак да су у наведеној методи у потпуности поштоване пропозиције које су дате у граматици „основног француског језика”, према којима се у настави француског као страног језика препоручују упитни облици у којима је употребљена проста инверзија или је очуван канонски ред речи посредством упитног израза est-ce que. Наиме, од 50 анализираних директних парцијалних питања, 39 (78\%) њих исказано је помоћу просте инверзије (нпр. Où voulez-vous aller, Monsieur?, Quand l'avez-vous trouvé?, Comment faites-vous?, Pourquoi êtes-vous fatigué?), a 10 (20\%) помоћу упитног израза est-ce que (нпр. Où est-ce qu'il s'en va?, Quand est-ce qu'il arrivera?, Pourquoi est-ce qu'il faut partir?). Према пропозицијама „основног француског језика” толерише се и облик директног парцијалног питања у коме је упитни прилог comment употребљен у иницијалној позицији, те је овај облик у наведеној методи забележен једанпут (2\%), и то у следећем примеру: Alors, mon vieux, comment ça va, après votre terrible accident?.

\section{Комуникативне методе}

Умерено конзервативна језичка норма. У методи Le nоиvеаи sans frontières, 1 (Dominique et al., 1988) тежи се томе да се посредством дијалога и докумената пружи „жива и аутентична представа језика", уз строго одређену лексичку и граматичку прогресију. У наведеној методи забележено је укупно 77 директних парцијалних питања уз упитне прилоге où, quand, comment и pourquoi, а међу њима има 58 упитних облика (75\%) који су изведени помоћу просте инверзије (нпр. Où préférez-vous habiter?, Quand est-il parti?, Comment vastu?, Pourquoi fait-elle ce gâteau?) и 8 (10\%) који су изведени помоћу сложене инверзије (нпр. Depuis quand Nicolas connaît-il Roland Brunot?, Depuis quand Agnès Darot a-t-elle commencé son enquête?, Pourquoi Agnès Darot interroge-t-elle Rémi Dupuis?, Pourquoi M. Dupuis est-il allé dans les Pyrénées?). У мањој мери забележени су упитни облици у којима је очуван канонски ред речи уз упитни прилог у иницијалној позицији, и то 3 облика (5\%) са упитним изразом est-ce que (Où est-ce que je peux acheter des disques d'Édith Piaf?, Où est-ce que vous êtes allé(e)?, Quand vous étiez enfant, où est-ce que vous habitiez ?) и 8 облика (10\%) без њега (нпр. Comment vous vous appelez?, Pourquoi vous n'avez pas donné votre adresse?, Pourquoi tu 
ne vas pas travailler?), а није забележен ниједан облик у коме би упитни прилог био у финалној позицији.

Метода Écho, Al (Girardet et al., 2008) настала је на темељима „акционог” приступа учењу страног језика (фр. une approche «actionnelle»). У складу са препорукама ЗЕРОЈ-а, ученик се посматра као будући друштвени актер који учи да испуњава одређене задатке у франкофоној средини служећи се разним вештинама (фр. savoirfaire, savoir-être, savoir-apprendre), и то кроз интеракцију, као основни вид подстицаја учења. Тежи се томе да комуникација у настави што више одражава реалне говорне ситуације и аутентичан начин изражавања изворних говорника. У наведеној методи забележено је укупно 88 директних парцијалних питања уз упитне прилоге où, quand, comment и pourquoi, међу којима предњаче они облици који су изведени помоћу просте инверзије (33 облика, 37,5\%, нпр. Oѝ vont-ils?, Quand êtes-vous libres?, Comment mangez-vous?, Pourquoi sors-tu?) и сложене инверзије (12 облика, 13,64\%, нпр. Quand et pourquoi cet article a-t-il été écrit?, Comment ce problème va-t-il être réglé?, Pourquoi la mer est-elle salée?). За разлику од претходно анализиране комуникативне методе, у методи Écho, Al (Girardet et al., 2008) у значајној мери су заступљени и упитни облици у којима је очуван канонски ред речи, уз упитни прилог употребљен у иницијалној позицији (21 облик, 23,86\%, нпр. Où vous habitez?, D'où vous venez?, Depuis quand tu habites à Paris?, Comment on prononce?, Alors, pourquoi ils ont fait ça?) или у финалној позицији (18 облика, 20,45\%, нпр. Tи habites où?, Elle est née quand?, Vous vous appelez comment?). Најмање је заступљен упитни облик изведен помоћу упитног израза est-ce que (4 облика, 4,55\%, нпр. Où est-ce que tu habites?, Quand estce qu'elle est née?, Pourquoi est-ce que tu arrives à 10h?).

Флексибилна језичка норма. У методи Тетро, 1 (Bérard et al., 1996) основни циљ који се настоји постићи у настави јесте оспособљавање ученика за комуникацију на француском језику у што разноврснијим говорним ситуацијама. Из тог разлога, лекције нису засноване на централним дијалозима помоћу којих би се уводило градиво које би се обрађивало у лекцији, него на низу разноврсних кратких докумената, аутентичних или осмишљених у педагошке сврхе, посредством којих се настоји што верније дочарати комуникација међу изворним говорницима и значај језичке варијације. Истиче се да је важно да ученици, већ од почетка учења, буду изложени различитим језичким регистрима, те да постепено уче како да своје изражавање прилагоде конкретној ситуацији (у ту сврху, саветује се и поређење са језичким регистрима у матерњем језику). Том основном циљу подређене су и граматичке, лексичке и фонетске вежбе. У првим лекцијама, нагласак се ставља на говорни језик, а у каснијим лекцијама често се врши поређење између говорног и писаног јези- 
ка. У наведеној методи забележено је 140 директних парцијалних питања, међу којима предњачи облик у коме је очуван канонски ред речи уз употребљен упитни прилог у финалној позицији (79 облика, 56,43\%, нпр. Vous habitez où?, Il est né quand?, Tu es allé à Paris comment?, Tu t'appelles comment?). Готово у истој мери заступљени су облици у којима је употребљена проста инверзија (27 облика, 19,29\%, нпр. Où va-t-il?, Quand part-il?, Comment allez-vous, Madame Lecomte?, Comment vous appelez-vous?) или је очуван канонски ред речи посредством упитног израза est-ce que (24 облика, 17,14\%, нпр. Où est-ce que vous habitez?, Quand est-ce que tu es arrivée en France?, Comment est-ce que vous vous appelez?). У најмањој мери су забележени они облици у којима је очуван канонски ред речи уз употребљен упитни прилог у иницијалној позицији (10 облика, 7,14\%, нпр. Où tu habites?, Et toi, comment tu t'appelles?, Pourquoi tu me demandes ça?, Pourquoi tu n'es pas venue au cours de yoga, hier soir?). Занимљиво је приметити да се на почетку учења, приликом систематизације градива које се односи на формирање упитних облика, не нуде упитни облици изведени помоћу инверзије. Наиме, усвојен је став према којем је потребно, од самог почетка учења, сензибилизовати ученике на различите начине постављања истог питања, али пошто инверзија захтева извесне синтаксичке промене и везује се пре за писани него за говорни језик, усвајање тих облика одлаже се за касније лекције.

Метода Escales, 1 (Blanc et al., 2002) инспирисана је, у великој мери, препорукама које су изнете у ЗЕРОЈ-у. У њој се јасно прави разлика између оног градива које треба да буде обухваћено вежбама усменог и писменог разумевања од градива за које се очекује да га ученик активно употребљава у вежбама усменог изражавања и изражавања у писаној форми. Аутори објашњавају да је „спектар онога што треба да разумемо нужно шири од онога што треба да знамо да искажемо" (Ibid., стр. 3). Овакво разграничавање омогућило им је да, кроз аутентичне документе, у вежбама разумевања понуде увид у језичку варијацију којом се одликује савремени француски језик. Они напомињу да је у методи представљен „,аутентичан језик, у који спадају различити језички регистри, а не само стандардни француски језик” (Ibid., стр. 3). Од 130 забележених директних парцијалних питања, као и у претходно анализираној методи, већина је изведена уз очуван канонски ред речи, коме следи упитни прилог у финалној позицији (63 облика, 48,46\%, нпр. Il va où?, Les vacances d'été, c'est quand?, Pour aller à Barbizon, on fait comment?, Vous vous appelez comment?). За разлику од претходно анализиране методе, у овој методи се и облик у коме је задржан канонски ред речи уз упитни прилог у иницијалној позицији (нпр. Où tu vas?, Comment tu vas?, Comment vous vous appelez?, Pourquoi vous me demandez ça, m'sieur?, 
Pourquoi tu ne parles pas à Antoine?) јавља чешће (32 облика, 24,62\%) од облика изведеног помоћу просте инверзије (28 облика, 21,54\%, нпр. Où allaient-ils?, Oui, quand voulez-vous venir?, Comment dit-on grand-mère, en français?, Comment vous appelez-vous?, Mais pourquoi voulez-vous aller à Barbizon?). Најмање су заступљени облици у којима је очуван канонски ред речи посредством упитног израза estce que (7 облика, 5,38\%, нпр. Où est-ce que c'est?, Quand est-ce que tu prends tes vacances?, Comment est-ce que vous vous appelez?, Mais pourquoi est-ce que tu veux aller au Québec?).

\section{ДИСКУСИЈА И ПЕДАГОШКЕ ИМПЛИКАЦИЈЕ}

Уколико упоредимо резултате нашег истраживања језичке варијације на примеру директног парцијалног питања уз упитне прилоге où, quand, comment и pourquoi у одабраним методама за почетни ниво учења француског као страног језика, долазимо до закључка да све анализиране методе показују заједничку карактеристику у погледу слабе заступљености упитног облика изведеног помоћу сложене инверзије. Међутим, добијени резултати који се односе на употребу просте инверзије знатно се разликују, те показују раскорак од апсолутне или доминантне заступљености овог облика у односу на остале упитне облике до његове потиснутости у други план, иза супстандарних упитних облика, којима се одликује разговорни француски језик. Наиме, у комуникативним методама, са придавањем веће пажње усменом виду испољавања језика над писаним, приметна је тенденција ка успостављању канонског реда речи у формулисању директног парцијалног питања уз упитне прилоге, што чини једну од основних карактеристика француског разговорног језика. Међутим, неусаглашен је начин на који се третирају поједини упитни облици који задржавају исти ред речи као у изјавној реченици: у методи $L e$ nouveau sans frontières, 1 (Dominique et al., 1988) даје се предност оним облицима у којима је упитни прилог употребљен непосредно у иницијалној позицији, а занемарује се његова употреба у финалној позицији, у методи Tетро, 1 (Bérard et al., 1996) доминантан је упитни облик у којем се упитни прилог налази у финалној позицији, а маргинализован је облик у коме се упитни прилог налази непосредно у иницијалној позицији, у методи Écho, Al (Girardet et al., 2008) ова два облика приближно се подједнако користе, након облика изведеног помоћу просте инверзије, док су у методи Escales, 1 (Blanc et al., 2002) ова два упитна облика доминантна над свим осталим упитним облицима. Када је реч о упитном облику у коме је канонски ред речи очуван посредством упитног израза est-ce que, он се ни не спомиње у методама Le Mauger Bleu (Mauger et al., 1953) и Франиуски: аудио-визуелна метода. Курс франиуског језика (Gauvenet 
et al., 1971), док се у методама Le nouveau sans frontières, 1 (Dominique et al., 1988), Escales, 1 (Blanc et al., 2002) и Écho, Al (Girardet et al., 2008) налази на последњем месту, а у методи Tempo, 1 (Bérard et al., 1996) на претпоследњем месту. Једини изузетак чини метода $L e$ Français et la vie, 1 (Mauger et al., 1971), у којој је наведени облик, у складу са пропозицијама граматике „основног француског језика”, у значајној мери заступљен (20\%).

Отежавајућу околност у изучавању језичке варијације у француском језику, па тако и језичких варијетета за исказивање упитног значења, представља чињеница да у лингвистичкој литератури која се бави како француским као страним тако и француским као матерњим језиком - не постоји доследан начин описа језичке варијације, те је она често заснована на квантитативно и квалитативно неусаглашеним критеријумима. У савременој настави француског као страног језика, лишени конзистентног објашњења о стилској вредности појединих језичких варијетета и њиховој употреби у методичкој пракси, наставници су често доведени у незгодан положај да сами решавају деликатно питање третирања језичке варијације. Наиме, са продором комуникативног приступа у наставу страних језика, управо због тога што језичка норма више није заснована на крутим прескриптивним начелима (као у случају le bon usage или, у извесној мери, „основног француског језика”), долази до извесних недоследности у њеном тумачењу, те ту можемо разликовати умерено конзервативан и флексибилан однос према језичкој норми. Како би се, у контексту наставе француског као страног језика, лакше савладали изазови које језичка варијација намеће, поједини дидактичари бирају компромисно решење и заузимају толерантнији однос према језичкој варијацији на нивоу рецепције, али имају рестриктиван однос према језичкој варијацији на нивоу продукције. Овакав став у складу је са препорукама изнетим у ЗЕРОJ-y (CECR, 2000, стр. 94), али није решено парадоксално питање како ученицима објаснити да не треба да следе модел усменог изражавања изворних говорника будући да је он често погрешан јер одступа од принципа језичке норме, која је заснована на писаном језику!

\section{ЗАКЉУЧАК}

Бавећи се језичком варијацијом у контексту наставе француског као страног језика, Жак Пол (Jacques Pohl) закључује да се свако ко предаје француски језик среће са „озбиљним и деликатним проблемом" који представља чињеница да постоје случајеви када одлично говорити француски језик заправо значи „говорити га помало и лоше" (Durán \& McCool, 2003, стр. 296). Ово тврђење могло би се применити и на учење структурних одлика директног парцијалног 
питања уз упитне прилоге où, quand, comment и pourquoi будући да савремене анализе француског језика показују да изворни говорници у свакодневном говору паралелно употребљавају стандарне и супстандардне облике за исказивање упитног значења, којима придају различите стилске одлике и који би, према томе, морали наћи своје место и у настави француског као страног језика. Указивање на значај језичке варијације, већ од ране фазе учења страног језика, у складу је са савременим методолошким тенденцијама, али примена ових начела у настави и доследан опис језичке варијације представљају посебан изазов за дидактичаре француског као страног језика, што се може закључити на основу резултата нашег истраживања употребе синтаксичких варијетета за исказивање директног парцијалног питања уз упитне прилоге où, quand, comment и pourquoi. Будући да формална и стилска неусаглашеност упитних облика у контексту наставе француског као страног језика може да доведе до несигурности у исказивању упитног значења и, самим тим, да изазове застој у развоју комуникативних способности изражавања, постоји изражена потреба ка њиховом подробнијем изучавању и доследнијем прагматичком дефинисању у складу са резултатима проучавања језичке варијације урађеним на опширним корпусима савременог француског говорног језика.

\section{ИЗВОРИ}

Bérard, É., Canier, Y. \& Lavenne, C. (1996). Tempo, 1. [Tempo, 1]. Paris: Didier, Hatier. Blanc, J., Cartier, J.-M. \& Lederlin, P. (2002). Escales, 1. [Stopovers, 1]. Paris: CLE International.

Dominique, P., Girardet, J., Verdelhan, M. \& Verdelhan, M. (1988). Le nouveau sans frontières, 1. [New Edition of Without Borders, 1]. Paris: Clé International.

Gauvenet, H., Guberina, P., Neveu, P., Rivenc, P. \& Vettier, R. (1971). Francuski: audiovizuelna metoda. Kurs francuskog jezika. [French: Audiovisual Teaching Method. French Language Course]. Zagreb: Jugoton-Didier tečajevi živih jezika po audiovizuelnoj metodi; Pariz: Didier.

Girardet, J., Pécheur, J. \& Gibbe, C. (2008). Écho, A1. [Echo, A1]. Paris: Clé International.

Mauger, G., Lamaison, J. \& Hameau, M.-A. (1953). Cours de langue et de civilisation françaises: à l'usage des étrangers, I ( $1^{e r}$ et $2^{e}$ degrés). [French Language and Civilization Courses: for Non-Native Speakers, I (First and Second Degrees)]. Paris: Hachette.

Mauger, G., Bruézière, M., Mercier, S. \& Geffroy, R. (1971). Le Français et la vie, 1. [French and Life, 1]. Paris: Hachette.

\section{ЛИТЕРАТУРА}

Bibeau, G. \& Germain, C. (1983). La norme dans l'enseignement de la langue seconde. [Norm in Second Language Teaching]. In: É. Bédard \& J. Maurais (Eds.). La norme linguistique (pp. 511-540). Québec: Conseil de la langue française, Gouvernement du Québec; Paris: Le Robert. Retrieved April 23, 2018 from the 
World Wide Web http://www.cslf.gouv.qc.ca/bibliotheque-virtuelle/publication$\mathrm{html} /$ ?tx_iggcpplus_pi4\%5bfile\%5d=publications/pubf101/f101p5a.html\#xix

Boyer, H. \& Rivera, M. (1979). Introduction à la didactique du français langue étrangère. [Introduction to Teaching French as a Foreign Language]. Paris: CLE International.

Boyer, H., Butzbach-Rivera, M. \& Pendanx, M. (1990). Nouvelle introduction à la didactique du français langue étrangère. [New Introduction to Teaching French as a Foreign Language]. Paris: CLE International.

CECR - Cadre européen commun de référence pour les langues: apprendre, enseigner, évaluer. [Common European Framework of Reference for Languages]. (2000). Strasbourg: Conseil de l'Europe, Division des Politiques Linguistiques. Retrieved April 23, 2018 from the World Wide Web http://www.coe.int///dg4/linguistic/ Source/Framework_ФP.pdf

Coste, D. (1969). Quel français enseigner ? [Which French to Teach?]. Le français dans le monde, 65, Numéro spécial: Guide pédagogique pour le professeur de français, 12-18.

Coveney, A. (2002). Variability in Spoken French. A Sociolinguistic Study of Interrogation and Negation. Bristol, Portland: Elm Bank.

Galisson, R. (1980). D'hier à aujourd'hui: la didactique générale des langues étrangères. Du structuralisme au fonctionnalisme. [From Yesterday until Today: General Approach to Foreign Language Teaching. From Structuralism to Functionalism]. Paris: CLE International.

Durán, R. \& McCool, G. (2003). If This Is French, Then What Did I Learn In School? The French Review, 77/2, 288-299.

Gougenheim, G., Michéa, R., Rivenc, P. \& Sauvageot, A. (1964). L'élaboration du français fondamental ( $1^{e r}$ degré). Étude sur l'établissement d'un vocabulaire et d'une grammaire de base. [Elaboration of the Fundamental French (First Degree). Study on the Basic Vocabulary and Grammar Selection]. Paris: Didier.

Valdman, A. (1982). Français standard et français populaire: sociolectes ou fictions? [Standard French and Colloquial French: Sociolects or Fictions?]. The French Review, 56/2, 218-227.

\title{
LINGUISTIC NORMS AND A RELATIONSHIP TOWARDS LINGUISTIC VARIATION IN TEACHING FRENCH AS A FOREIGN LANGUAGE: EXAMPLES OF THE USE OF DIRECT PARTIAL QUESTION WITH INTERROGATIVE ADVERBS
}

\author{
Nataša Radusin-Bardić \\ University of Novi Sad, Faculty of Philosophy, Novi Sad, Serbia
}

\section{Summary}

The syntax structures for expressing interrogative modality in French and, in particular, for expressing the direct partial question with interrogative adverbs "où", "quand", "comment" and "pourquoi", show a high degree of variation. Namely, native speakers use several forms, in parallel, to express the same interrogative meaning but 
with different stylistic values: on the one hand, forms with the free or complex inversion following an interrogative adverb in the initial position are used for literary, especially written language while, forms which preserve the word from the original statement (subject + predicate + object) are associated with spoken language. The latter category includes those partial questions in which the canonical word order is preserved by using the interrogative expression "est-ce que" after the interrogative adverb in the initial position, but also those in which the interrogative adverb in initial position is used directly, as well as questions in which the interrogative adverb is used in final position. Although linguistic norms prescribe the obligatory use of inversions after interrogative adverbs in the initial position, the analysis of contemporary French spoken language shows that native speakers mostly use those interrogative forms, whereas in informal speech there is omission, and especially with a directly used interrogative adverb in the initial or final position.

The subject of our paper is the analysis of the use of various forms for expressing a direct partial question with interrogative adverb "où", "quand", "comment" and "pourquoi" in methods for learning French as a foreign language published from the middle of the last century and up to the present. We wanted to see how linguistic variations and deviations from the linguistic norms in spoken language were treated by the dominant methodological directions that marked the modern teaching of the French language by analyzing the representation of these interrogative adverbs in representative methods for teaching French as a foreign language during the mentioned period. For the purposes of our research, we selected seven initial methods for teaching French as a foreign language: one traditional grammatical method based on the language code of the French literary language ("le bon usage"); two audio-visual methods based on the norms of the "basic French language"; two communicative methods in which the linguistic norm is moderately conservative; as well as two communicative methods in which linguistic norms are flexible.

Our results show that all analyzed methods have a common characteristic in terms of the poor representation of the interrogative form derived from a complex inversion. However, when it comes to the use of simple inversion, the results differ significantly and show a disruption in the absolute or dominant representation of this form in relation to the other interrogative forms, until it has been pushed down, renouncing its position to substandard interrogative forms characterized by the French spoken language. The inconsistencies are particularly noticeable in the communicative methods precisely because linguistic norms are no longer predetermined and based on rigid prescriptive principles, but rather take a moderately conservative or flexible stance towards linguistic norms. In contemporary teaching of French as a foreign language, teachers are often deprived of a consistent explanation of the stylistic value of certain linguistic varieties for expressing the interrogative meaning and its use in methodical practice, and so there is a strong need for a more detailed study and a more consistent pragmatic definition based on an analysis of the corpus of the contemporary French spoken language. 